\title{
Sustain release Formulation and Evaluation of Ofloxacin floating delivery system
}

\author{
Anand J. Patel, Deep R. Naik, Jignesh P. Raval ${ }^{\star}$ \\ Department of Chemistry, Uka Tarsadia University, Maliba Campus, Gopal Vidyanagar, Bardoli- \\ Mahuva Road, Tarsadi- 394 350, Tal: Mahuva, Dist: Surat, Gujarat, India
}

*E-mail address: drjpraval@gmail.com

\begin{abstract}
Floating tablets has been accepted as a process to achieve controlled drug delivery by prolonging the residence time of the dosage form at the site of absorption, thereby improving and enhancing the bioavailability of drug. The objective of present study outlines the development and characterization the floating drug delivery system of Ofloxacin to enhance its bioavailability and therapeutic efficacy, using different grades of polymer along with effervescent agent sodium bicarbonate and citric acid. Ofloxacin is a synthetic chemotherapeutic second-generation antibiotic of the fluoroquinolone class. Different tablet formulations were formulated by wet granulation technique and were evaluated for physical parameters like Tablet Thickness, Hardness, \% Friability, Weight variation, Content uniformity, In vitro buoyancy, Swelling index, In vitro dissolution study and drug release mechanisms. As the concentration of the polymer in the formulations increased the release of drug decreased. Hence it was considered as suitable candidate for formulation as floating drug delivery system. Different kinetic models were applied to drug release data in order to evaluate release mechanisms and kinetics. The optimized formula F4 showed better sustained drug release with good floating properties and fitted best to be Korsmeyer-Peppas model with $\mathrm{R}^{2}$ value of 0.9575 . As the $\mathrm{n}$ value for the Korsmeyer- Peppas model was found be more than 0.5 it follows Non-Fickian diffusion mechanism. FTIR result showed that there is no drug excipients interaction.
\end{abstract}

Keywords: Ofloxacin; Ethyl Cellulose; Xanthum Gum; Floating Drug delivery System; Controlled Release

\section{INTRODUCTION}

The aim of oral controlled drug delivery system is to deliver drugs for longer period of time and to achieve better bioavailability. To achieve this goal, it would be advantageous and more convenient to maintain a dosing frequency to once, or at most, a twice-daily regimen [1]. In conventional oral drug delivery systems, there is little or no control over the release of the drug, and effective concentration of grossly excessive doses [2]. But this is difficult due to number of physiological problems such as fluctuation in the gastric emptying process, narrow absorption window and stability problem in the intestine [3]. To overcome these 
problems oral controlled dosage form with gastro retentive properties were developed [4]. These include bioadhesive or mucoadhesive systems [5], swelling and expanding systems $[6,7]$, floating systems [8,9] and other delayed gastric emptying devices. The principle of floating preparation offers a simple and practical approach to achieve increased gastric residence time for the dosage form and sustained drug release [10].

Ofloxacin is an anti-bacterial agent that inhibits an enzyme called DNA gyrase which is essential component of the mechanism that passes genetic information onto daughter cells when a cell divides. Ofloxacin exhibits $\mathrm{pH}$ dependent solubility. It is more soluble in acidic $\mathrm{pH}$ and slightly soluble in neutral or alkaline $\mathrm{pH}$ conditions [11,12]. Ofloxacin is a fluoroquinolone [13,14], broad spectrum antibiotic, rapidly well absorbed from the gastrointestinal tract. Half life of Ofloxacin is 9 hours and is used in the treatment of genitourinary, respiratory, gastrointestinal, skin and soft tissue infections [15]. Development of a gastro retentive drug delivery system of propranolol hydrochloride shows that the tablets formulated using HPC, sodium alginate, HPMC E15 LV failed to produce matrix of required strength, while formulation containing xanthum gum showed good drug retaining abilities but floating abilities were found to be poor [16]. Finally, floating tablets were formulated with Ethyl cellulose, cross povidone and HPC which would increase the bioavailability of Ofloxacin and also to reduce frequency of administration, thereby improving patient compliance and therapeutic efficacy.

The present study aims in designing floating tablets of Ofloxacin by wet granulation technique using HPC, Ethyl Cellulose, Cross povidone, Xanthum Gum along with effervescent agent sodium bicarbonate and citric acid. The prepared tablets are also evaluated for physicochemical properties, buoyancy lag time, and total floating time, swelling index, in-vitro drug release and Release Mechanism.

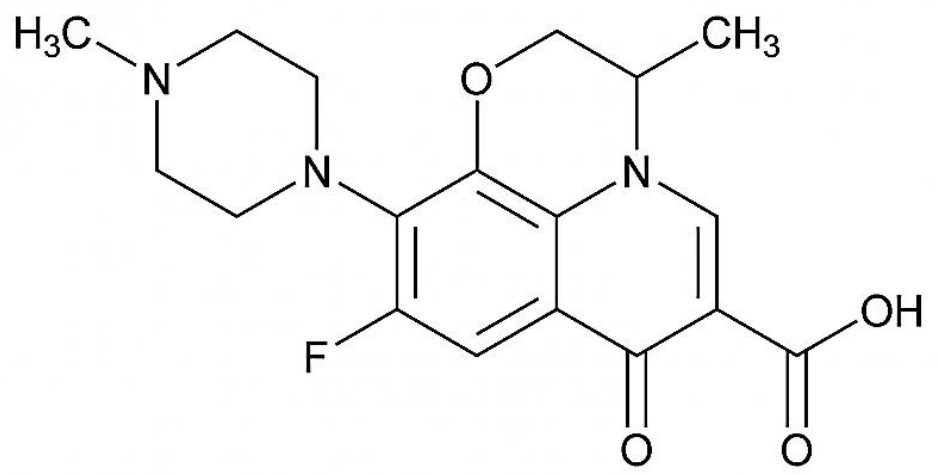

Scheme 1. Ofloxacin: $(R S)$-7-fluoro-2-methyl-6-(4-methylpiperazin-1-yl)-10-oxo-4-oxa-1azatricyclo[7.3.1. $\left.0^{5,13}\right]$ trideca-5(13),6,8,11-tetraene-11-carboxylic acid.

\section{EXPERIMENTAL}

\section{1. Materials}

Ofloxacin was procured as a gift sample from Balaji drug supplier (Surat, Gujarat, India). Hydroxy Propyl Cellulose and Cross Povidone was purchase from Balaji drug supplier (Surat, Gujarat, India). Ethyl Cellulose was purchased from Aldrich Chemical 
Company, Inc. (Milwaukee, WI, USA). Xanthum Gum, Sodium Bicarbonate, Magnesium Stearate, Citric acid and Talc was purchased from S.D. Fine Chemicals (Mumbai, India).

\section{2. Fabrication of Ofloxacin Floating Tablets}

Floating tablets were prepared by conventional wet granulation. The composition of different formulations of Ofloxacin floating tablets is shown in Table 1. All the intragranular ingredients except PVP were passed through sieve no. 40 \#. Now add $5 \% \mathrm{w} / \mathrm{w}$ PVP-K30 in isopropyl alcohol solution until wet mass is formed. The wet mass was passed through sieve $16 \#$ and the granules were dried at $60{ }^{\circ} \mathrm{C}$ for $1 \mathrm{hr}$ in a hot air oven. The dried granules were passed through sieve $22 \#$ and lubricated with magnesium stearate and talc by further blending for $3 \mathrm{~min}$. Tablets were compressed at $530 \mathrm{mg}$ weight on a 10 station mini rotary tableting machine with $12 \mathrm{~mm}$ flat shaped punches.

Table 1. Composition of different formulations for Ofloxacin Floating Tablets.

\begin{tabular}{|c|c|c|c|c|c|c|c|c|c|}
\hline $\begin{array}{c}\text { Batch } \\
\text { No }\end{array}$ & Ofloxacin & $\begin{array}{c}\text { Hydroxyl } \\
\text { Propyl } \\
\text { Cellulose }\end{array}$ & $\begin{array}{c}\text { Ethyl } \\
\text { Cellulose }\end{array}$ & $\begin{array}{c}\text { Cross } \\
\text { Povidone }\end{array}$ & $\begin{array}{c}\text { Xanthum } \\
\text { Gum }\end{array}$ & $\mathbf{N a H C O}_{3}$ & $\begin{array}{c}\text { Citric } \\
\text { Acid }\end{array}$ & $\begin{array}{c}\text { Magnesium } \\
\text { Stearate }\end{array}$ & Talc \\
\hline & $\mathbf{m g}$ & $\mathbf{m g}$ & $\mathbf{m g}$ & $\mathbf{m g}$ & $\mathbf{m g}$ & $\mathbf{m g}$ & $\mathbf{m g}$ & $\mathbf{m g}$ & $\mathbf{m g}$ \\
\hline F1 & 400 & 72 & -- & -- & 10 & 25 & 30 & 1 & 2 \\
\hline F2 & 400 & 82 & -- & -- & 15 & 20 & 20 & 2 & 1 \\
\hline F3 & 400 & -- & 72 & -- & 10 & 25 & 30 & 1 & 2 \\
\hline F4 & 400 & -- & 82 & -- & 15 & 20 & 20 & 2 & 1 \\
\hline F5 & 400 & -- & -- & 72 & 10 & 25 & 30 & 1 & 2 \\
\hline F6 & 400 & -- & -- & 82 & 15 & 20 & 20 & 2 & 1 \\
\hline
\end{tabular}

\section{3. Evaluation of Granules}

\section{3. 1. Angle of repose}

Angle of repose was determined using funnel method [17]. The blend was poured through a funnel that can be raised vertically until a maximum cone height (h) was obtained. Radius of the heap (r) was measured and angle of repose $(\theta)$ was calculated using the following formula:

$$
\theta=\tan ^{-1}(\mathrm{~h} / \mathrm{r})
$$

\section{3. 2. Bulk density}

Apparent bulk density $\left(\rho_{\mathrm{b}}\right)$ was determined by pouring the blend into a graduated cylinder. The bulk volume $(\mathrm{Vb})$ and weight of the powder $(\mathrm{M})$ was determined. The bulk density $\left(\rho_{b}\right)$ was calculated using following formula [17],

$$
\rho_{\mathrm{b}}=\frac{\mathrm{Vb}}{\mathrm{M}}
$$




\section{3. 3. Tapped density}

The measuring cylinder containing a known mass of blend $(\mathrm{M})$ was tapped for a fixed time (100 tapping). The minimum volume $\left(\mathrm{V}_{\mathrm{t}}\right)$ occupied in the cylinder and weight of the blend was measured. The tapped density $\left(\rho_{t}\right)$ was calculated using following formula [17],

$$
\rho_{\mathrm{t}}=\frac{\mathrm{Vt}}{\mathrm{M}}
$$

\section{3. 4. Hausner's ratio $(\mathrm{H})$}

This is an indirect index of ease of powder flow. It is calculated by the following formula [15],

$$
H=\frac{\rho_{\mathrm{t}}}{\rho_{\mathrm{b}}}
$$

where $\rho_{\mathrm{t}}$ indicates the tapped density; $\rho_{\mathrm{b}}$ indicates the bulk density.

\section{3. 5. Compressibility index or Carr's Index}

The simplest method of measurement of free flow of powder is compressibility. An indication of the ease with which material can be induced to flow is given by compressibility index (I) which is calculated as follows [17],

$$
I=\frac{\rho_{\mathrm{t}}-\rho_{\mathrm{b}}}{\rho_{\mathrm{t}}} \times 100
$$

where $\rho_{\mathrm{t}}$ indicates the tapped density; $\rho_{\mathrm{b}}$ indicates the bulk density.

\section{4. Evaluation of Ofloxacin Floating tablets}

\section{4. 1. Hardness}

The prepared tablets hardness was measured by using Monsanto hardness tester. The hardness was measured in terms of $\mathrm{kg} / \mathrm{cm}^{2}[18]$.

\section{4. 2. Friability}

The tablets were weighed collectively and placed in the chamber of the friabilator. After 100 rotation (i.e. in 4 minutes), the tablets were taken out from friabilator and intact tablets were again weighed collectively [18].

\section{4. 3. Weight variation}

Twenty tablets were selected at random and weighed individually. The individual weights were compared with the average weight for determination of weight variation. The percentage deviation was calculated and then compared with USP specifications [18]. 


\section{4. 4. Thickness}

Thickness of prepared tablets was analyzed by vernier calipers and the average was calculated [18].

\section{4. 5. Drug content}

Five tablets were powdered in a mortar. An accurately weighed quantity of powdered tablets $(100 \mathrm{mg}$ ) was extracted with $0.1 \mathrm{~N} \mathrm{HCl}$ (pH 1.2 buffer) and the solution was filtered through $0.45 \mu$ membranes. Each extract was suitably diluted and analyzed spectrophotometrically at $294 \mathrm{~nm}$ [19].

\section{4. 6. In Vitro Buoyancy Studies}

The in vitro buoyancy was determined by floating lag time. The tablets were placed in a $100 \mathrm{ml}$ beaker containing $\mathrm{pH} 1.2$ buffers. The time required for the tablet to rise to the surface and float was determined as floating lag time. This test was performed on 3 tablets from each batch [20].

\section{4. 7. Determination of Swelling Index}

The swelling index of tablets was determined in $0.1 \mathrm{~N} \mathrm{HCl}(\mathrm{pH} \mathrm{1.2)}$ at room temperature. The swollen weight of the tablet was determined at predefined time intervals over a period of $24 \mathrm{~h}$. The swelling index (SI), expressed as a percentage, and was calculated from the following equation. The percentage weight gain by the tablet was calculated by the formula [21].

$$
\text { Swelling index (S. I. })=\left\{\frac{W_{t}-W_{o}}{W_{o}}\right\} \times 100
$$

where, S.I. $=$ Swelling index; $\mathrm{Wt}=$ Weight of tablet at time $\mathrm{t}$ and $\mathrm{Wo}=$ Weight of tablet before immersion

\section{4. 8. In vitro drug release studies}

The in vitro drug release study was conducted using the USP dissolution apparatus-II (paddle method) and $900 \mathrm{ml}$ of $0.1 \mathrm{~N} \mathrm{HCl}(\mathrm{pH} \mathrm{1.2)}$ as dissolution release medium. The study was conducted at $37 \pm 0.5{ }^{\circ} \mathrm{C}$ and at paddle rotation of $50 \mathrm{rpm}$. The tablet was placed inside the dissolution vessel. $5 \mathrm{ml}$ of sample were withdrawn at predetermined time intervals. The volume of dissolution fluid was adjusted to $900 \mathrm{ml}$ by replacing $5 \mathrm{ml}$ of fresh dissolution medium after each sampling. The release studies were performed in triplicate, and the mean values were plotted versus time. Each sample was analyzed at $293 \mathrm{~nm}$ using double beam UV - Visible Spectrophotometer against reagent blank [22].

\section{4. 9. Drug release kinetics}

Various models were tested for explaining the kinetics of drug release. To analyze the mechanism of the drug release rate kinetics of the dosage form, the obtained data were fitted into zero-order [23], first order [24], Higuchi [25], and Korsmeyer-Peppas [26] release model. 


\section{5. Characterization of Ofloxacin Floating Tablets}

\section{5. 1. FTIR studies}

Pure drug, and optimized formulation (F4) were subjected for FTIR analysis using Fourier transformer infrared spectrophotometer (8600, Shimadzu Corporation, Japan). The samples were prepared on $\mathrm{KBr}$-press (Spectra Lab, India) and scanned over wave number range of 4000 to $400 \mathrm{~cm}^{-1}$. Spectra were analyzed for drug polymer interactions and functional groups.

\section{RESULTS AND DISCUSSION}

\section{1. Pre-formulation studies for the Granules}

Granules prepared for compression of floating matrix tablets were evaluated for their flow properties like angle of repose, bulk density, tapped density and compressibility index. The results were shown in Tables 2. The bulk density of the granules was in the range of 0.3365 to $3660 \mathrm{gm} / \mathrm{ml}$; the tapped density was in the range of 0.3794 to $4545 \mathrm{gm} / \mathrm{ml}$, which indicates that the granules were not bulky. The Hausner's ratio was found to be in the range of 1.07 to 1.24 . The Compressibility index was found to be in the range of 7.50 to $20.60 \%$ indicating that the powder blends has good flow properties which was further confirmed by Angle of repose was in the range of $26.09^{\circ}$ to $33.69^{\circ}$.

Table 2. Granules properties of formulations F1 to F6 for Ofloxacin floating tablets.

\begin{tabular}{|c|c|c|c|c|c|}
\hline Batch no & $\begin{array}{c}\text { Angle of } \\
\text { repose (⿶) }\end{array}$ & $\begin{array}{c}\text { Bulk } \\
\text { density } \\
(\mathbf{g m} / \mathbf{m l})\end{array}$ & $\begin{array}{c}\text { Tapped } \\
\text { density } \\
(\mathbf{g m} / \mathbf{m l})\end{array}$ & $\begin{array}{c}\text { Carr's } \\
\text { index (\%) }\end{array}$ & $\begin{array}{c}\text { Hausner's } \\
\text { ratio }\end{array}$ \\
\hline F1 & $28.94^{\circ}$ & 0.3550 & 0.4142 & 16.97 & 1.16 \\
\hline F2 & $29.88^{\circ}$ & 0.3756 & 0.4295 & 14.35 & 1.14 \\
\hline F3 & $30.51^{\circ}$ & 0.3529 & 0.3794 & 7.50 & 1.07 \\
\hline F4 & $26.09^{\circ}$ & 0.3660 & 0.4414 & 20.60 & 1.20 \\
\hline F5 & $32.12^{\circ}$ & 0.3386 & 0.4027 & 18.93 & 1.18 \\
\hline F6 & $33.69^{\circ}$ & 0.3365 & 0.4545 & 24.01 & 1.24 \\
\hline
\end{tabular}

\section{2. Evaluation of Ofloxacin floating tablets.}

The thicknesses of floating tablets were measured by vernier caliper and were ranged between 4.10 to $4.15 \mathrm{~mm}$. Hardness of the tablets was in the range of 5.5 to $6.0 \mathrm{~kg} / \mathrm{cm}^{2}$. This ensures that tablets have good handling characteristics of all the batches.

Tablet 3. Evaluation of Ofloxacin floating tablets.

\begin{tabular}{|c|c|c|c|c|c|}
\hline Batch no & $\begin{array}{c}\text { Hardness } \\
\left(\mathbf{k g} / \mathbf{c m}^{\mathbf{2}}\right)\end{array}$ & Friability (\%) & $\begin{array}{c}\text { Weight } \\
\text { Variation } \\
(\mathbf{\%})\end{array}$ & $\begin{array}{c}\text { Thickness } \\
(\mathbf{m m})\end{array}$ & $\begin{array}{c}\text { Drug } \\
\text { content } \\
(\boldsymbol{\%})\end{array}$ \\
\hline F1 & 5.6 & $0.17 \%$ & $539 \pm 2.6$ & 4.12 & 99.42 \\
\hline F2 & 5.5 & $0.24 \%$ & $541 \pm 2.6$ & 4.11 & 98.43 \\
\hline
\end{tabular}




\begin{tabular}{|l|l|l|l|l|l|}
\hline F3 & 6.1 & $0.19 \%$ & $542 \pm 4.0$ & 4.15 & 100.91 \\
\hline F4 & 5.6 & $0.13 \%$ & $540 \pm 1.9$ & 4.10 & 100.72 \\
\hline F5 & 5.8 & $0.27 \%$ & $538 \pm 1.9$ & 4.11 & 102.05 \\
\hline F6 & 5.5 & $0.20 \%$ & $540 \pm 2.6$ & 4.15 & 101.03 \\
\hline
\end{tabular}

The friability was below $1 \%$ for all the formulations, ensuring that the tablets were mechanically stable. All the formulated tablets (F1 to F6) passed the weight variation test as the $\%$ weight variation was within the Pharmacopoeial limits of $\pm 5 \%$ of weight. The percentage of drug content was found to be $99.43 \%$ to $102.05 \%$ of Ofloxacin, which was within the permissible limits. Table 3 shows the results of Evaluation parameters of tablets.

The tablet floating lag time (FLT) was found to be less than $30 \mathrm{~s}$ and total floating time more than $10 \mathrm{~h}$. The floating lag time may be explained as a result of the time required for dissolution medium to penetrate the tablet matrix and develop the swollen layer for entrapment of $\mathrm{CO}_{2}$ generated in situ. The relative influence of tablet excipients on floating lag time may be explained in the light of FLT model in Table 4. Both the swelling polymers penetrate the tablet matrix and develop the swollen layer for entrapment of $\mathrm{CO}_{2}$ generated in situ. In the present study the higher swelling index was found for tablet of F4 containing 70 mg EC. The concentration of polymer and ratio of Xanthum Gum had major influence on swelling process, matrix integrity, as well as floating capability, hence from the above results it can be concluded that linear relationship exists between swelling process and concentration ratio as shown in Table 5.

Table 4. Buoyancy studies of Ofloxacin floating Tablets.

\begin{tabular}{|c|c|c|}
\hline \multicolumn{3}{|c|}{ Bouncy study } \\
\hline Batch no & Floating time (sec) & Total floating time (hrs) \\
\hline F1 & 82 & $<12$ \\
\hline F2 & 91 & $<12$ \\
\hline F3 & 98 & $<12$ \\
\hline F4 & 78 & $<12$ \\
\hline F5 & 94 & $<12$ \\
\hline
\end{tabular}

Table 5. Swelling Index of Ofloxacin floating tablets.

\begin{tabular}{|c|c|c|c|c|}
\hline \multicolumn{5}{|c|}{ Swelling study } \\
\hline \multirow{2}{*}{ Batch no } & \multicolumn{4}{|c|}{ Time in Hrs (\% swelling) } \\
\cline { 2 - 5 } & $\mathbf{2}$ & $\mathbf{4}$ & $\mathbf{6}$ & $\mathbf{8}$ \\
\hline F1 & 61.70 & 88.32 & 62.11 & 15.20 \\
\hline F2 & 45.30 & 60.98 & 54.30 & 20.90 \\
\hline F3 & 30.22 & 45.41 & 47.96 & 30.29 \\
\hline F4 & 58.49 & 86.22 & 61.29 & 16.56 \\
\hline F5 & 43.50 & 62.29 & 56.54 & 27.75 \\
\hline F6 & 60.50 & 85.50 & 75.32 & 24.38 \\
\hline
\end{tabular}




\section{3. In vitro drug release study of Ofloxacin floating tablets}

In vitro drug release studies exhibited a decrease drug release with an increase in polymer concentration which may be due to increase in viscosity of the gel as well as the gel layer with longer diffusion path.

Formulations containing high viscosity grade EC showed slower drug release compared to formulations containing low viscosity polymers. There was no considerable effect of gas generating agents on the release of the drug.

Drug release profile of batches of Ofloxacin floating tablet F1, F2, F3, F4, F5, F6 showed $84.75 \%, 87.58 \%, 94.61 \%, 96.10 \%, 84.10 \%$ \& $85.29 \%$ respectively. This showed that the drug release from the tablet was sustained for 8 to $12 \mathrm{hr}$. Graphical representation drug release profile of all the batches were shown in Figure 1.

From the graph considered the \% release of F4 formulation is maximum i.e. due to increase amount of Ethyl cellulose.

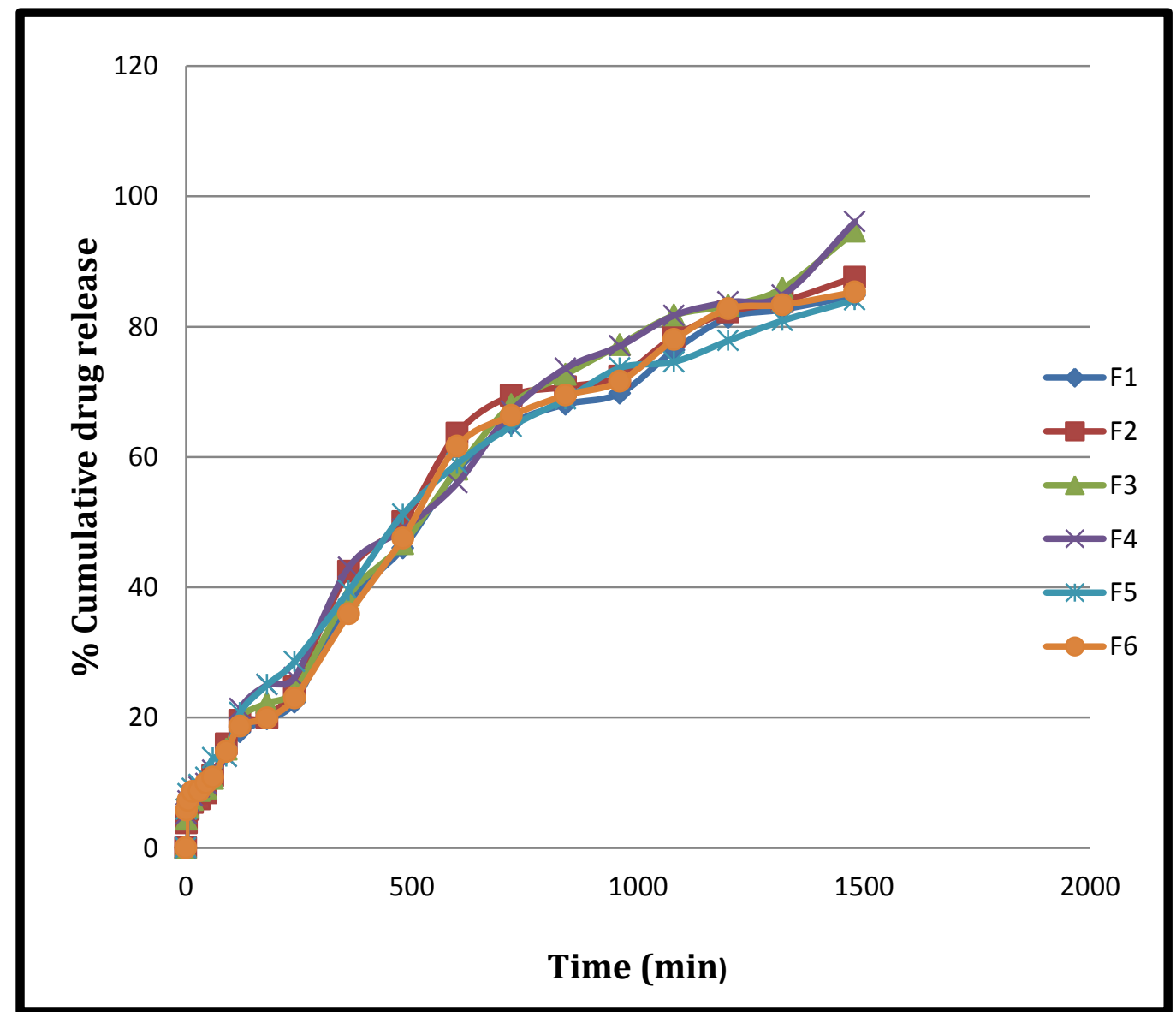

Figure 1. In vitro drug release study of Ofloxacin floating tablets.

\section{3. 1. Drug Release Kinetics}

The in vitro release kinetics was carried out by fitting the release data to models representing zero-order, first-order, and Higuchi's square root of time. The correlation coefficient of different kinetic models for all the formulations containing various polymers is tabulated in Table 6. 
Table 6. Release data of different model for Ofloxacin Floating Tablet.

\begin{tabular}{|c|c|c|c|c|c|c|c|c|}
\hline \multirow{2}{*}{$\begin{array}{c}\text { Batch } \\
\text { No. }\end{array}$} & \multicolumn{2}{|c|}{ Zero order } & \multicolumn{2}{|c|}{ First order } & \multicolumn{2}{c|}{ Higuchi } & \multicolumn{2}{c|}{$\begin{array}{c}\text { Korsmeyer- } \\
\text { Peppas model }\end{array}$} \\
\cline { 2 - 9 } & $\mathbf{R}^{\mathbf{2}}$ & $\mathbf{k}_{\mathbf{0}}$ & $\mathbf{R}^{\mathbf{2}}$ & $\mathbf{k}_{\mathbf{1}}$ & $\mathbf{R}^{\mathbf{2}}$ & $\mathbf{k}_{\mathbf{h}}$ & $\mathbf{R}^{\mathbf{2}}$ & $\mathbf{N}$ \\
\hline F1 & 0.9697 & 5.1460 & 0.9550 & 0.0771 & 0.9557 & 21.221 & 0.9455 & 0.63504 \\
\hline F2 & 0.9525 & 5.7103 & 0.9477 & 0.0787 & 0.9533 & 23.563 & 0.9270 & 0.65864 \\
\hline F3 & 0.9862 & 5.0546 & 0.9289 & 0.0740 & 0.9668 & 20.966 & 0.9519 & 0.64956 \\
\hline F4 & 0.9820 & 4.9713 & 0.8993 & 0.0717 & 0.9780 & 20.888 & 0.9508 & 0.68759 \\
\hline F5 & 0.9755 & 5.1443 & 0.9368 & 0.0707 & 0.9808 & 21.432 & 0.9575 & 0.61296 \\
\hline F6 & 0.9660 & 5.3999 & 0.9651 & 0.0776 & 0.9402 & 22.132 & 0.9524 & 0.60075 \\
\hline
\end{tabular}

Figure 2-to-5. shows graphical representation for various Release kinetics model. It was found that all the formulations were best fit into Higuchi's square root release model. It confirmed that the drug is very slowly diffusing out of the polymer matrices showing a much sustained release. To examine the mechanism of release the data were fitted to KorsmeyerPeppas model. According to Korsmeyer-Peppas, a value of the exponent, $n=0.5,0.5<n<1$, $n=1.0$ indicates Fickian diffusion, non-Fickian diffusion and Case II transport, respectively. The $\mathrm{R}^{2}$ values of Korsmeyer-Peppas release as well as $\mathrm{R}^{2}$ values of zero order release pattern for all formulations were near one. The $\mathrm{n}$ value of Korsmeyer-Peppas model of all formulations was between 0.60 and 0.68 .

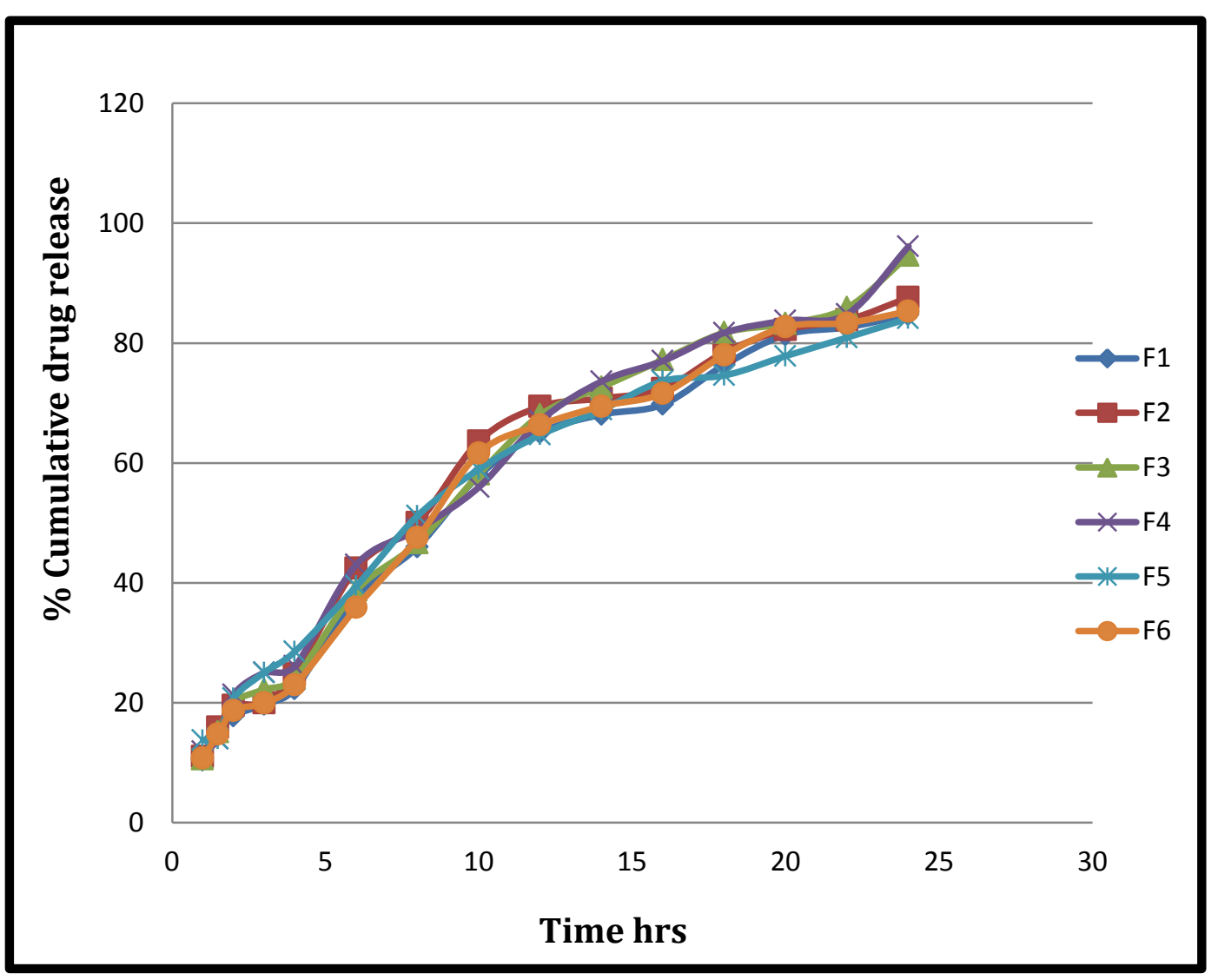

Figure 2. Zero order release kinetics. 


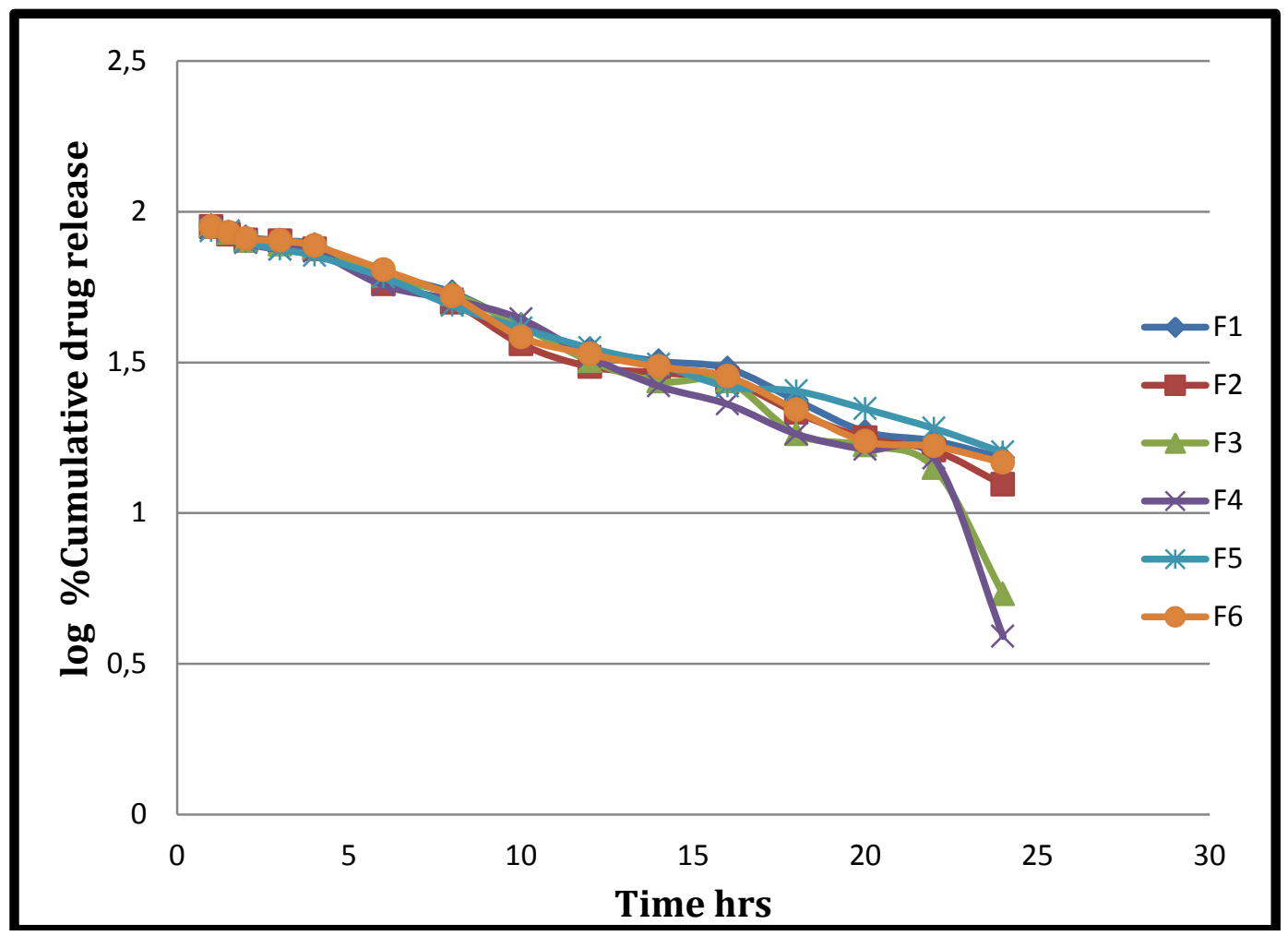

Figure 3. First order release kinetics.

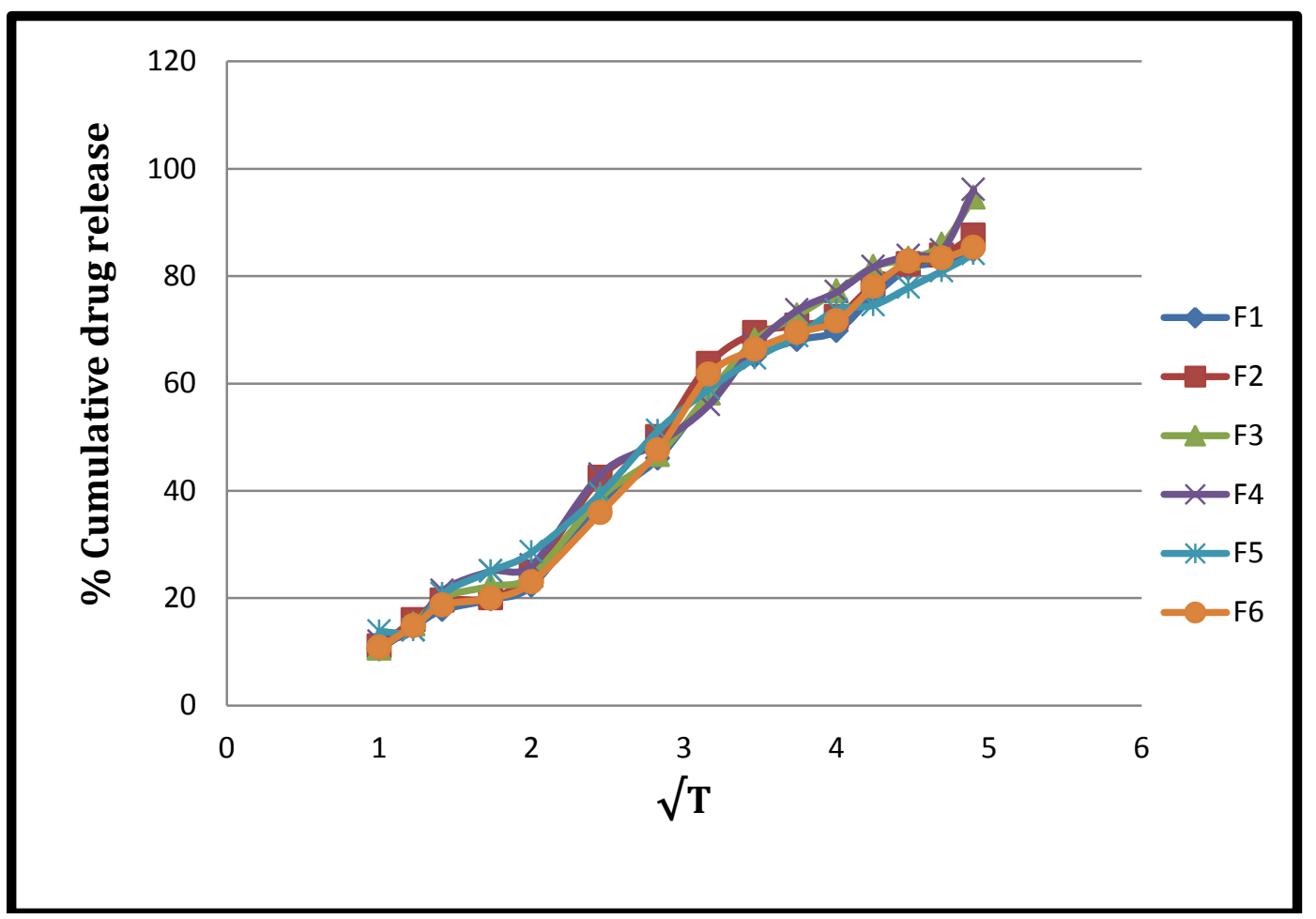

Figure 4. Higuchi kinetic release profile. 


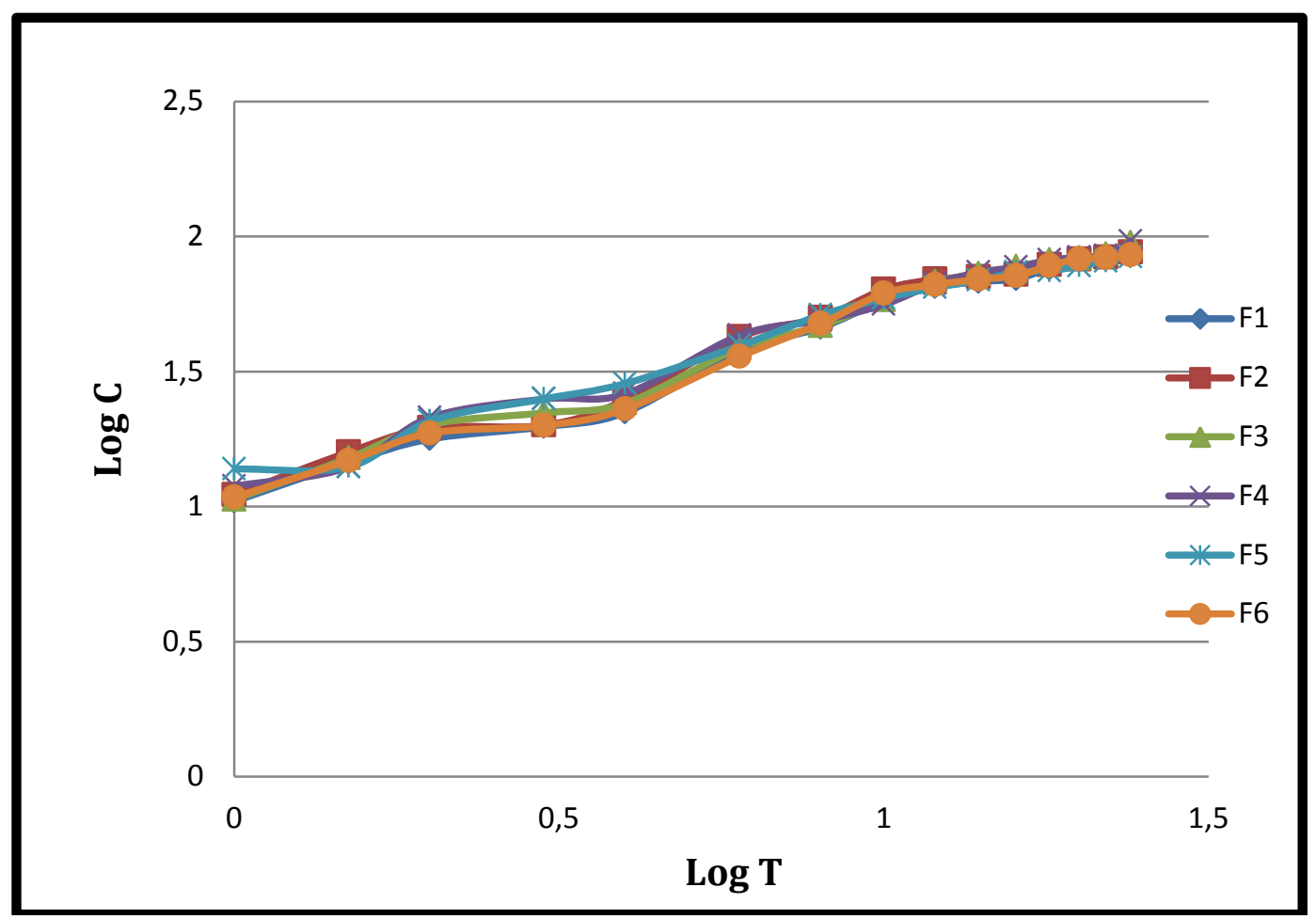

Figure 5. Korsmeyer-Peppas release profile.

To examine the mechanism of release the data were fitted to Korsmeyer-Peppas model. According to Korsmeyer-Peppas, a value of the exponent, $n=0.5,0.5<n<1, n=1.0$ indicates Fickian diffusion, non-Fickian diffusion and Case II transport, respectively. The $\mathrm{R}^{2}$ values of Korsmeyer-Peppas release as well as $\mathrm{R}^{2}$ values of zero order release pattern for all formulations were near one. The $\mathrm{n}$ value of Korsmeyer-Peppas model of all formulations was between 0.60 and 0.68 . Therefore, the most probable mechanism that the release patterns of all formulations followed was Non-Fickian diffusion or anomalous diffusion. Wherein the drug release mechanism is controlled by both diffusion as well as polymer relaxation process. Since no lag-time was observed in the dissolution of any of the developed formulations, it may be inferred that the swellable polymers could not turn into gel immediately in contact with dissolution fluid, thereby giving an initial higher release rate from the tablets.

\section{4. FTIR Studies}

FTIR spectra and Characteristic peaks for pure drug and polymer, optimized formulation F4 were represented in Figure 6-7. Compatibility studies were performed using FTIR spectrophotometer.. From the FTIR spectrum, it was concluded that no significant shift in peak pattern in IR spectrum of drug, polymer, excipients.

\section{CONCLUSIONS}

In the present investigation gastric retentive system of Ofloxacin were prepared with HPC and EC polymers. Ofloxacin has site-specific absorption in the upper part of the 
stomach and hence these systems are useful in the improving the absorption of the drug. It was found that increase in the EC concentration will decrease floating lag time and increases floating duration but decrease drug release.

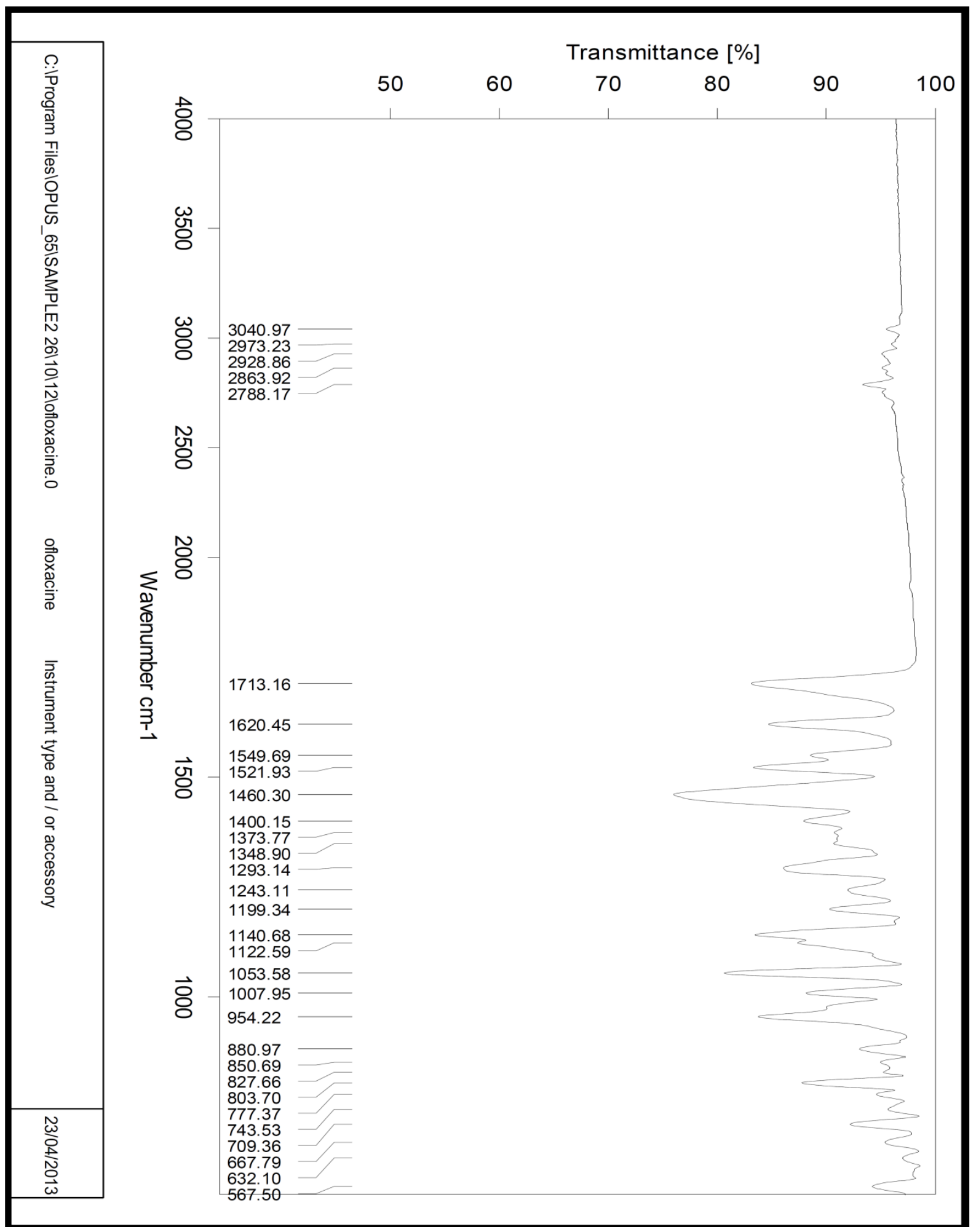

Figure 6. FTIR Spectra of Ofloxacin. 


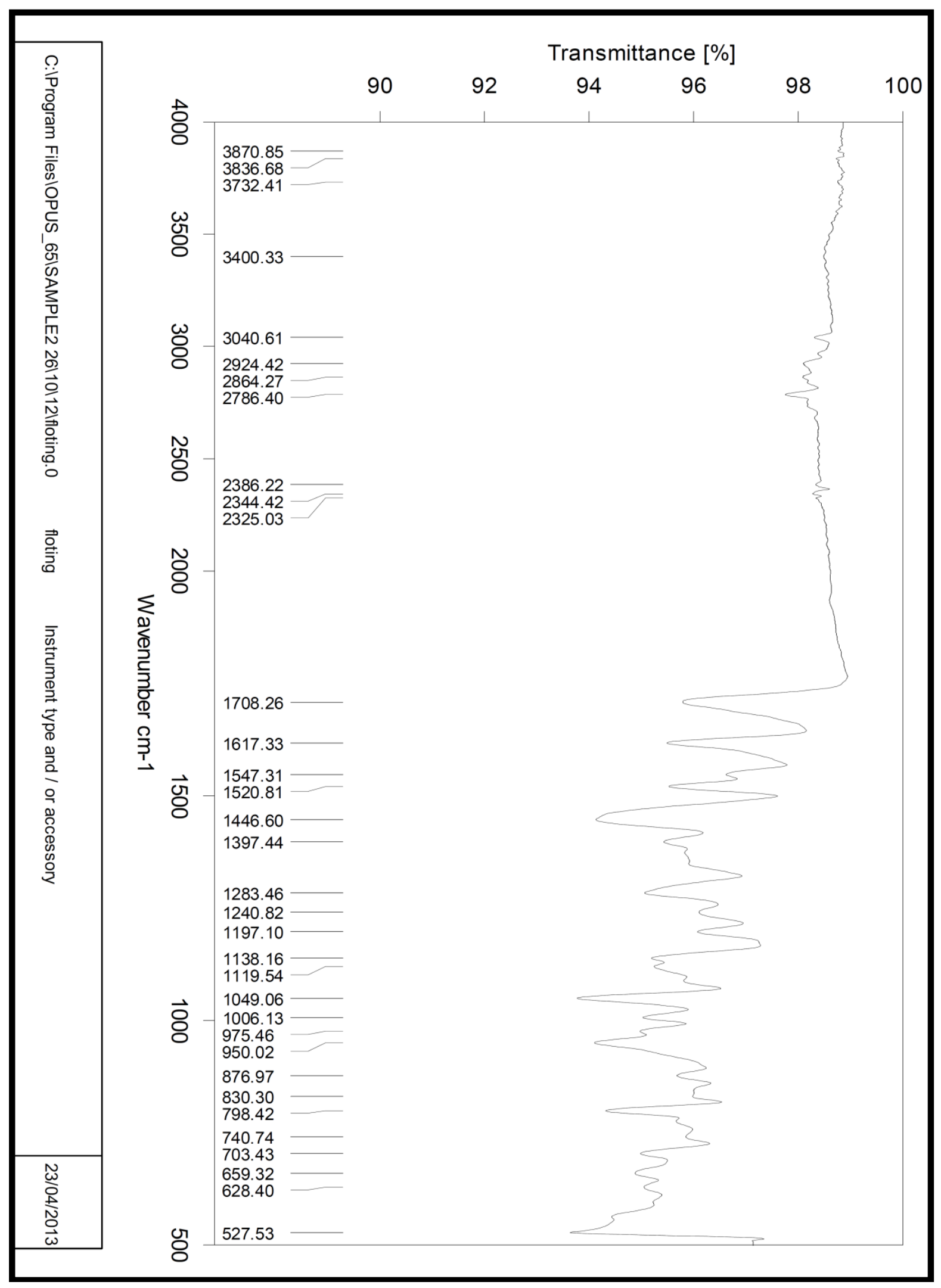

Figure 7. FTIR studies of Formulation F4. 
Tablet was subjected to various evaluation parameters such as physical property, floating property, swelling property, and in-vitro drug release studies. It was revealed that all batches had acceptable physical parameters. All tablet formulation had good floating property along with swelling behaviors and in-vitro drug release. It was found that increase in the EC concentration will decrease floating lag time and increases floating duration but decrease drug release. FT-IR studies revealed that there was no interaction between Ofloxacin and other excipients used in the tablets.

The effervescent based floating drug delivery was a promising approach to achieve in vitro buoyancy. The addition of gel forming polymer and gas generating agent sodium bicarbonate was essential to achieve in vitro buoyancy. The drug release from the tablet was sufficiently sustained for $24 \mathrm{hr}$ and Non Fickian transport of the drug from tablet was confirmed, so drug release appears to be a complex mechanism of swelling, diffusion and erosion.

\section{ACKNOWLEDGMENT}

Authors would like to thank Department of Chemistry, Uka Tarsadia University, Maliba campus, Bardoli, Gujarat, India, for providing all the necessary research facilities. Authors would also like to thank SICART, Vallabh Vidyanagar, Anand, Gujarat, India for analytical characterization.

\section{References}

[1] Brahma, S.; Kwon, K., J. Chem. Pharm. Sci., 63 (2000) 235-259.

[2] Cargill, R.; Caldwell, L.; Engle, K.; Fix, J.; Porter, P.; Gardner, C., Pharm. Res. 5 (1998) 533-536.

[3] Gangadharappa, V.; Pramod, M.; Shiva, G. Ind. J Pharm. Edu. Res. 41(4) (2007) 295303.

[4] Streubel, A.; Siepmann, J.; Bodmeier, R., Expert Opinion Drug Delivery 3(2) (2007) 217-233.

[5] Santus, G.; Lazzarini, G.; Bottoni, G., Eur. J Pharm. Biopharm. 44 (1997) 39-52.

[6] Deshpande, A.; Rhodes, T.; Shah, H.; Malick, W., Drug Deliv. Ind. Pharm. 22 (1996) 531-539.

[7] Deshpande, A.; Rhodes, T.; Shah, H.; Malick, W., Pharm. Res. 14 (1997) 815-819.

[8] Menon, A.; Ritshel, A.; Sakr, A., J Pharm. Sci. 83 (1998) 239-245.

[9] Whitehead, L.; Fell, T.; Collett, H.; Sharma, L.; Smith, M., J Control Release, 55 (1998) 3-12.

[10] Patel, M.; Patel, M.; Pandya, M.; Jogani, D., Indian J Pharm. Sci. 69(6) (2007) 763767.

[11] Janardhan, D.; Joginapally, S.; Bharat, V.; Subramaniam, P., Int. J. Pharm. Sci. Nanotech. 1 (2009) 428-434.

[12] Padmavathy, J.; Saravanan, D.; Rajesh, D., Int. J Pharm. Pharm. Sci. 3(1) (2011) 170173. 
[13] V. J. Faldu, P. K. Talpara, N. H. Bhuva, P. R. Vachharajani, V. H. Shah, International Letters of Chemistry, Physics and Astronomy 6 (2014) 26-32

[14] Vipul C. Kotadiya, Denish J. Viradiya, Bharat H. Baria, Jayendra S. Kanzariya, Rajesh Kakadiya, Anamik Shah, International Letters of Chemistry, Physics and Astronomy 11(3) (2014) 265-276.

[15] Boldhane, P.; Kuchekar, S., Curr. Drug Delivery 6(5) (2009) 477-485.

[16] Jagdale, C.; Agavekar, J.; Pandya, V.; Kuchekar, S.; Chabukswar, R., AAPS 10(3) (2009) 1071-1079.

[17] Jaimini, M.; Rana, C.; Tanwar, S., Curr. Drug Delivery 4 (2007) 51-55.

[18] Lachman, L.; Liberman, H.A.; Kanig, J.L., The Theory and Practice of Industrial Pharmacy, 3rd ed, Mumbai, Varghese publishing house, (1990) 296-302.

[19] Patil, P.; Rao, S.; Kulkarni, S.; Basavaraj.; Surpur, C.; Ammanage, A., Asian J Res. Pharm. Sci., 1(1) (2011) 17-22.

[20] Rosa, M.; Zia, H.; Rhodes, T., Int. J Pharm. 105 (1994) 65-67.

[21] Lalla, K.; Gurnancy, A., Indian Drugs 39 (2002) 270-276.

[22] Veerareddy, P.; Bajjuri, S.; Sanka, S.; Jukanti, R.; Bandari, S.; Ajmeru, V.; Rao, A., Stamford J. Pharm. Sci. 4(1) (2011) 09-18.

[23] Donbrow, M.; Samuelov, Y., J. Pharm. Pharmacology 32 (1961) 463-470.

[24] Merchant, A.; Shoaib, M.; Tazeen, J.; Yousuf I., AAPS 7(3) (2006) 78-86.

[25] Higuchi, T., J. Pharm. Sci. 52 (2006) 1145-1149.

[26] Korsmeyer R., Gurny R., Docler E., Buri P., Peppas A., Int. J. Pharmacy 15 (1983) 2535. 